PENGELUARAN KESEHATAN

RUMAH TANGGA DI PULAU JAWA

DIBANDINGKAN DENGAN LUAR

\section{PULAU JAWA}

Diterima 30 Juli 2016

Disetujui 26 Desember 2016

Dipublikasikan 1 Februari 2017

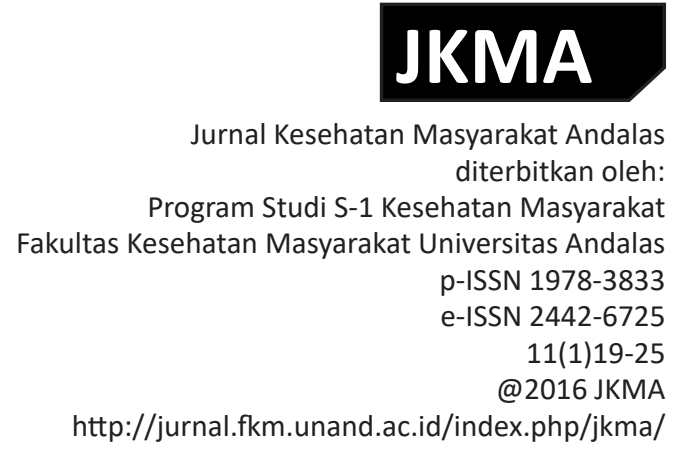

Jurnal Kesehatan Masyarakat Andalas diterbitkan oleh:

p-ISSN 1978-3833

11(1)19-25

@2016 JKMA

Wira Iqbal $^{1 凶}$, Mubassyir Hasan Basri², Limawan Budiwibowo ${ }^{3}$

${ }^{1}$ Dinas Kesehatan Kabupaten Tanah Datar, Sumatera Barat

${ }^{2}$ Departemen Kesehatan Masyarakat, Fakultas Kedokteran, Universitas Gajah Mada, Yogyakarta

${ }^{3}$ Dinas Kesehatan Kabupaten Klaten, Jawa Tengah

\begin{abstract}
Abstrak
Pembiayaan kesehatan merupakan kunci utama dalam suatu sistem kesehatan di berbagai negara. Penelitian ini bertujuan untuk mengetahui pengeluaran rumah tangga untuk biaya kesehatan di Indonesia, serta untuk mengetahui pengaruh letak geografis, status ekonomi dan kepemilikan asuransi terhadap pengeluaran rumah tangga untuk biaya kesehatan di Indonesia. Jenispenelitianiniadalahpenelitiananalitik dengan rancangan cross-sectional yang akan menjelaskan hubungan pengeluaran rumah tangga untuk biaya kesehatan. Unit analisis penelitian ini adalah data susenas 2011.Penelitian ini menunjukkan bahwa status ekonomi, lokasi geografis serta status asuransi berpengaruh terhadap besarnya biaya kesehatan rumah tangga sebulan di Indonesia. Dari sisi ekonomi bahwa pengeluaran rumah tangga miskin untuk kesehatan memang jauh lebih rendah dari rumah tangga kaya.Ada perbedaan yang berarti antara Jawa dan luar Jawa, ini lebih nyata pada kelompok kaya.Rumah tangga yang memiliki asuransi jamkesmas mengeluarkan biaya jauh lebih kecil dibanding rumah tangga yang memiliki asuransi jenis lainnya. Penelitian ini menemukan pengeluaran biaya kesehatan rumah tangga di Pulau Jawa lebih tinggi dari pada luar Pulau Jawa, dan masih adanya pengeluaran rumah tangga untuk biaya kesehatan pada kelompok termiskin yang mana pemerintah sudah melakukan penjaminan dengan program Jamkesmas, Jamkesda dan Jampersal.
\end{abstract}

Kata Kunci: Pengeluaran Kesehatan Rumah Tangga, Pembiayaan Kesehatan

\title{
HOUSEHOLD EXPENDITURE FOR JAVA IN HEALTH COSTS COMPARED TO THE ISLAND JAVA
}

\begin{abstract}
The Health funding is a key element in the health system in various countries. This study aims to determine the cost of household expenditure on health in Indonesia. As well as to determine the effect of geografis location, economic status and ownership of insurance against household expenditure for health care costs in Indonesia. This research is analytic study with cross-sectional design that will explain the relationship of household expenditures for health care costs. The unit of analysis of this research is the data susenas in 2011. This study shows that the economic status, geographical location and insurance status affects the amount of health care costs households a month in Indonesia. In terms of the economic status of poor households that spending on health is considerably lower than richer households. There are significant differences between Java and outside Java, this is more evident on the rich. In terms of insurance status, type of insurance affect the amount of costs incurred, households with a health card insurance pay far less than households that have other types of insurance. This study found that household spending on health care costs in Java is higher than outside Java, and the persistence of household spending on health care costs in the poorest group in which the government has done with the guarantee program jamkesmas, Jamkesda and Jampersal.
\end{abstract}

Keywords: Household Health Expenditure, Health Financing 


\section{Pendahuluan}

Permasalahan pembiayaan kesehatan merupakan kunci utama dalam suatu sistem kesehatan di berbagai negara. Ukuran terpenting dari sistem pendanaan yang adil adalah bahwa beban dari biaya kesehatan dari kantong perorangan tidak memberatkan penduduk. Aspek pendanaan yang adil tersebut diartikan sebagai pendanaan kesehatan yang adil dan merata atau merata keadilan (equity). ${ }^{(1)}$

Penduduk miskin biasanya mengeluarkan porsi yang lebih besar dari pengeluaran non makanannya untuk kesehatan dibandingkan dengan penduduk kaya.(2) Pembayaran out of pocket (OOP) tidak menurun dengan rendahnya kemampuan membayar bisa menjadi indikasi yaitu kurangnya peran asuransi kesehatan. Hal tersebut menyiratkan bahwa masyarakat harus membayar dari OOP untuk mengamankan kualitas pelayanan kesehatan mereka.

Tidak adanya pembagian resiko atau mekanisme pembayaran menimbulkan hambatan keuangan untuk konsumsi pelayanan kesehatan oleh masyarakat miskin. ${ }^{(3)}$ Asuransi me ngurangi biaya pelayanan kesehatan, dan dapat menurunkan beban OOP pengeluaran kesehatan pada rumah tangga dan resiko pemiskinan yang terkait dengan penyakit. ${ }^{(4)}$

Jarak ke penyedia layanan kesehatan merupakan faktor penting dalam menentukan pilihan penyedia. Oleh karena itu, merancang paket manfaat yang sesuai bagi orang-orang yang tinggal di daerah pedesaan harus mencakup penyedia layanan kesehatan yang berada di masyarakat sekitarnya. ${ }^{(5)}$

Menurut sensus penduduk tahun 2010, jumlah penduduk Indonesia 237.641.326 jiwa, $57.5 \%$ penduduk Indonesia terkonsentrasi di Pulau Jawa dengan luas wilayah 6,8\% dan diluar Pulau Jawa sebesar $42.5 \%$ dengan luas wilayah $93,2 \%$ dari total wilayah Indonesia. ${ }^{(6)}$ Akses ke sarana pelayanan kesehatan secara nasional berdasarkan hasil Riset Kesehatan Dasar tahun 2010, sebanyak 94,1\% rumah tangga berada kurang atau sama dengan $5 \mathrm{~km}$ dari salah satu sarana pelayanan kesehatan dan sebanyak 90,8\% rumah tangga dapat mencapai sarana pelayanan kesehatan kurang atau sama dengan 30 menit. ${ }^{(7)}$
Berdasarkan latar belakang di atas, maka permasalahan yang ingin dipecahkan dalam penelitian ini adalah; Bagaimana pengeluaran rumah tangga untuk biaya kesehatan di Indonesia, Apakah ada perbedaan pengeluaran rumah tangga untuk biaya kesehatan di Pulau Jawa dibandingkan dengan luar Pulau Jawa, dan Bagaimana hubungan status sosial ekonomi dan kepemilikan asuransi pada rumah tangga dengan pengeluaran kesehatan rumah tangga.

\section{Metode}

Subjek penelitian adalah rumah tangga di Indonesia. Jumlah keseluruhan rumah tangga yang menjadi responden Susenas tahun 2011 adalah sebanyak 55.307.385 rumah tangga. Penetapan responden menggunakan teknik total sampling dengan kriteria inklusi adalah rumah tangga yang menjadi responden dalam susenas, serta mengeluarkan biaya untuk kesehatan selama 3 bulan terakhir saat survei dilakukan, setelah disesuaikan dengan kriteria inklusi penelitian ini maka sampelnya menjadi 38.143.327 rumah tangga.

Analisis data yang digunakan dalam penelitian ini dilakukan secara univariat dan bivariat. Pemaparan deskriptif variabel-variabel yang terdapat dalam penelitian yaitu pengeluaran rumah tangga untuk biaya kesehatan sebagai variabel dependen dan sebagai variabel independen adalah status asuransi, status ekonomi, serta letak geografis rumah tangga.

\section{Hasil dan Pembahasan}

Adanya pengeluaran pada kelompok termiskin di Pulau Jawa maupun di luar Pulau Jawa mengindikasikan bahwa pemerintah belum optimal dalam memberikan perlindungan pada kelompok miskin terhadap terjadinya pengeluaran OOP pada pelayanan kesehatan.

Pada tabel 1 dapat dilihat bahwa berdasarkan lokasi geografis rumah tangga jumlah responden di Pulau Jawa terbanyak pada kelompok miskin, sementara di luar pulau jawa responden terbanyak pada rumah tangga kelompok hampir miskin.

Berdasarkan sumber asuransi, rumah tangga yang tidak mempunyai asuransi memi- 


\begin{tabular}{|c|c|c|c|c|c|c|c|c|}
\hline \multirow{3}{*}{ Variabel } & \multicolumn{8}{|c|}{ Status ekonomi } \\
\hline & \multicolumn{2}{|c|}{ Miskin } & \multicolumn{2}{|c|}{ Hampir miskin } & \multicolumn{2}{|c|}{ Kaya } & \multicolumn{2}{|c|}{ Total } \\
\hline & $\begin{array}{l}\text { Absolut } \\
\text { (ribuan) }\end{array}$ & $\%$ & $\begin{array}{l}\text { Absolut } \\
\text { (ribuan) }\end{array}$ & $\%$ & $\begin{array}{l}\text { Absolut } \\
\text { (ribuan) }\end{array}$ & $\%$ & $\begin{array}{l}\text { Absolut } \\
\text { (ribuan) }\end{array}$ & $\%$ \\
\hline \multicolumn{9}{|l|}{ Lokasi Geografis : } \\
\hline Jawa & 9,935 & 26 & 8,811 & 23 & 4,283 & 11 & 23,029 & 60 \\
\hline Luar Jawa & 5,466 & 14 & 6,433 & 17 & 3,215 & 8 & 15,115 & 40 \\
\hline Total & 15,401 & 40 & 15,244 & 40 & 7,499 & 20 & 38,143 & 100 \\
\hline \multicolumn{9}{|l|}{ Asuransi : } \\
\hline Askes & 242 & 1 & 1,114 & 3 & 1,507 & 4 & 2,863 & 8 \\
\hline Jamsostek & 297 & 1 & 1,087 & 3 & 883 & 2 & 2,266 & 6 \\
\hline Asuransi kesehatan swasta & 35 & 0 & 114 & 0 & 284 & 1 & 433 & 1 \\
\hline Penggantian dari perusahaan & 89 & 0 & 189 & 0 & 202 & 1 & 480 & 1 \\
\hline Jamkesmas / JPKM lain & 5,182 & 14 & 3,087 & 8 & 592 & 2 & 8,861 & 23 \\
\hline Lebih dari satu jaminan & 195 & 1 & 443 & 1 & 639 & 2 & 1,277 & 3 \\
\hline Tidak mempunyai asuransi & 9,360 & 25 & 9,211 & 24 & 3,392 & 9 & 21,963 & 58 \\
\hline Total & 15,401 & 40 & 15,244 & 40 & 7,499 & 20 & 38,143 & 100 \\
\hline
\end{tabular}

liki responden terbanyak, sementara rumah tangga yang memiliki asuransi yang bersumber dari jamkesmas/JPKM lain memiliki responden terbanyak dibanding rumah tangga lain yang memiliki asuransi, dan juga pada kelompok ekonomi kaya masih ditemui rumah tangga yang menggunakan asuransi jamkesmas, sedangkan pada kelompok ekonomi miskin masih terdapat keluarga yang tidak mempunyai asuransi.

Pengeluaran kesehatan pada kelompok miskin bisa terjadi karena masih terjadinya kesalahan dalam penetapan keluarga miskin oleh pemerintah yang mengakibatkan masih adanya rumah tangga miskin yang belum mendapatkan jaminan kesehatan sementara rumah tangga yang termasuk pada kelompok diatasnya justru mendapatkan jaminan kesehatan dari pemerintah. Sesuai dengan hasil penelitian Lorenz yang menyatakan perkiraan pengeluaran yang tidak akurat dapat menyebabkan stakeholder membuat pilihan-pilihan kebijakan yang berpotensi merugikan atau bahkan keputusan yang salah. Data keluarga miskin, setelah diterbitkan tidak diteliti menyeluruh dan cepat diterima sebagai fakta, sehingga kadang-kadang keliru dalam membuat kebijakan. ${ }^{(8)}$ Masyarakat miskin dan mere- ka yang tinggal di daerah yang secara ekonomi kurang berkembang memiliki resiko terbesar pengeluaran out-of pocket. ${ }^{(9)}$

Berdasarkan lokasi geografis rumah tangga, pengeluaran kesehatan pada semua kelompok ditemukan bahwa rumah tangga yang berdomisili di Pulau Jawa mengeluarkan biaya kesehatan yang lebih besar dari pada rumah tangga yang berdomisili di Pulau Jawa. Tingginya pengeluaran kesehatan di Pulau Jawa bisa terjadi karena banyaknya rumah sakit swasta serta rumah sakit khusus dengan tenaga spesialistik yang lebih lengkap di Pulau Jawa yang juga memiliki sarana penunjang yang lengkap serta dengan tarif yang biasanya lebih tinggi dari pada rumah sakit yang terdapat di luar Pulau Jawa.

Dengan adanya rumah sakit swasta dengan layanan yang biasanya lebih baik dari rumah sakit pemerintah mengakibatkan masyarakat yang memiliki asuransi kesehatan biasanya cenderung memilih memanfaatkan unit layanan tersebut dibandingkan rumah sakit pemerintah meskipun dengan konsekwensi mereka harus mengeluarkan biaya tambahan, yang bisa disebabkan karena pada saat mengakses pelayanan tidak dilakukan sesuai prosedur yang disepakati ataupun karena 
adanya permintaan atau tuntutan pasien untuk ditangani dokter spesialis di rumah sakit. Sesuai dengan pernyataan Hendrartini bahwa dokter di Jawa pada umumnya mempunyai proporsi rujukan kurang baik yang lebih tinggi dibanding dokter di luar Jawa. Tingginya angka rujukan di Jawa mungkin dipengaruhi oleh akses ke dokter spesialis dan rumah sakit yang relatif mudah, baik ketersediaan maupun jaraknya. ${ }^{(10)}$

Akses yang sulit ke pelayanan kesehatan di daerah luar Pulau Jawa mengakibatkan adanya pengeluaran kesehatan OOP bagi rumah tangga miskin karena untuk mendapatkan pelayanan mereka harus menempuh jarak yang jauh dan kadang sulit. Akibatnya mereka mengeluarkan biaya untuk perjalanan tersebut yang bahkan biayanya lebih besar daripada biaya layanan kesehatan itu sendiri.

Reformasi harus bertujuan untuk mengurangi hambatan untuk akses ke pelayanan kesehatan masyarakat dan juga mengidentifikasi kendala yang menghambat pemerataan dan akses pelayanan kesehatan masyarakat bagi masyarakat umum khususnya bagi masyarakat miskin dan penduduk di pedesaan. ${ }^{(1)}$ Sesuai juga dengan pernyataan Sulku, S Nur reformasi pelayanan kesehatan dalam hal keterjangkauan pelayanan kesehatan dan perlindungan finansial, dengan mengukur keterjangkauan pelayanan kesehatan dalam sistem pelayanan kesehatan. ${ }^{(9)}$

Erliyana menunjukkan bahwa penduduk pedesaan yang jarak ke penyedia layanan kesehatan merupakan faktor penting dalam menentukan pilihan penyedia. Sementara dikalangan penduduk perkotaan, harga penyedia layanan kesehatan merupakan faktor penting yang menentukan pilihan individu terhadap penyedia layanan kesehatan. ${ }^{(5)}$

Sparrow menemukan bahwa program Askeskin ditujukan kepada orang miskin dan orang-orang yang paling rentan terhadap bencana out-of-pocket pembayaran kesehatan. Asuransi kesehatan masyarakat meningkatkan akses ke pelayanan kesehatan dalam hal meningkatkan pemanfaatan pelayanan kesehatan rawat jalan di kalangan orang miskin, sementara pengeluaran out-of-pocket tampak- nya telah meningkat untuk Askeskin di daerah perkotaan. ${ }^{(12)}$

Parker \& Wong menyatakan bahwa kelompok yang paling responsif terhadap perubahan tingkat pendapatan adalah kelompok berpenghasilan rendah yang tidak diasuransikan. ${ }^{(13)}$ Banyaknya penduduk yang pergi ke tenaga medis juga dipengaruhi kondisi sosial-ekonomi masyarakat tersebut. Semakin baik kondisinya maka perbandingan antara jumlah yang sakit dengan yang pergi ke tenaga medis semakin besar rasionya. ${ }^{(14)}$

Berdasarkan jenis asuransi yang dimiliki oleh rumah tangga ditemukan masih ada pengeluaran kesehatan di kelompok miskin pada semua jenis asuransi, pengeluaran terkecil terdapat pada asuransi kesehatan swasta dan pengeluaran terbesar terjadi pada rumah tangga yang memiliki asuransi lebih dari satu. Sementara pada kelompok hampir miskin pengeluaran terkecil justru terjadi pada rumah tangga yang tidak memiliki asuransi dan pengeluaran terbesar pada rumah tangga yang memiliki jaminan lebih dari satu, untuk kelompok kaya pengeluaran terkecil terjadi pada rumah tangga yang memiliki Jamsostek dan pengeluaran tertinggi terjadi pada rumah tangga yang memiliki jaminan penggantian dari perusahaan.

Pengeluaran kesehatan yang terjadi pada semua jenis asuransi pada kelompok miskin, hampir miskin bahkan pada kelompok kaya ini mengindikasikan belum maksimalnya mekanisme asuransi dalam melindungi anggotanya terhadap terjadinya OOP pada rumah tangga dalam mengakses pelayanan kesehatan.

Pengeluaran OOP ini tentu saja memberatkan bagi rumah tangga terutama pada kelompok miskin dan juga kelompok hampir miskin, karena adanya biaya kesehatan pada kelompok ini bisa menyebabkan terganggunya stabilitas ekonomi rumah tangga atau lebih spesifiknya adanya biaya OOP tersebut bisa menyebabkan rumah tangga pada kelompok miskin dan hampir miskin terpaksa mengurangi kebutuhan dasar lainnya atau bisa juga mereka terpaksa untuk menjual harta benda yang mereka miliki bahkan mereka terpaksa meminjam uang untuk membayar biaya kesehatan OOP tersebut. 
Sesusai dengan penelitian Lorenz yang menyatakan pembayaran OOP memiliki substansial efek negatif, karena mereka tidak melindungi seseorang dari biaya berobat. Mereka dapat menyebabkan pemiskinan dan penderitaan bagi pasien, karena fakta bahwa orangorang miskin sering sakit, sehingga mereka mungkin tidak memiliki uang untuk membayar pengobatan mereka. Karena penyakit tetap tidak diobati karena kurangnya dana, atau pasien kehilangan sedikit uang yang mereka miliki dan berakhir sangat membutuhkan. Hasilnya mungkin bahwa orang-orang miskin mencari perawatan kurang dan tetap dalam lingkaran antara penyakit dan kemiskinan. ${ }^{(8)}$

Hal ini sesuai dengan Survei Xu et al di delapan puluh sembilan negara yang meliputi 89 persen dari populasi dunia menunjukkan bahwa 150 juta orang di dunia menderita bencana keuangan setiap tahun karena mereka membayar untuk pelayanan kesehatan. ${ }^{(15)}$

Kebanyakan sistem asuransi, terutama swasta, tidak memberikan jaminan bahwa anggota mereka tidak akan menghadapi biaya OOP. Bahkan Asuransi menyisakan banyak penerima asuransi dengan Biaya OOP tinggi karena gagal untuk memasukkan cakupan obat resep dan memiliki OOP tinggi dikurangkan dan pembagian biaya dengan persyaratan. ${ }^{(16)}$

Besarnya pengeluaran rumah tangga yang memiliki sumber asuransi kesehatan swasta daripada yang tidak mempunyai asuransi menimbulkan pertanyaan tentang efisiensi dari asuransi tersebut, yang seharusnya dengan ikut asuransi akan lebih kecil resiko tingginya pengeluaran kesehatan, apakah dengan memiliki asuransi rumah tangga menjadi lebih sering memanfaatkan layanan kesehatan sehingga justru menambah dari pengeluaran kesehatan itu sendiri ataukah karena masyarakat yang tidak memiliki asuransi yang lebih jarang mengunjungi unit layanan kesehatan ataupun jika terpaksa harus dirawat di rumah sakit lebih memilih kelas perawatan terendah.

Tingginya pengeluaran asuransi kesehatan swasta bisa disebabkan karena dalam memberikan manfaat perusahaan asuransi memberikan batasan-batasan tertentu seperti lama masa perawatan di rumah sakit ataupun jenis obat tertentu yang tidak ditanggung, ataupun juga jenis penyakit tertentu yang sudah diderita sebelum jadi peserta.

Sementara pada rumah tangga yang memiliki asuransi dari askes PNS juga terjadi biaya OOP yang biasanya disebabkan oleh beberapa hal seperti: kurangnya cakupan obat yang ditanggung untuk penyakit-penyakit tertentu atau keinginan dari peserta mendapatkan obat tertentu yang tidak terdapat dalam daftar plafon harga obat (DPHO) askes, pemilihan kelas perawatan yang lebih tinggi atau juga karena tidak menggunakan kartunya,

Adanya kecenderungan kebijakan di kabupaten/kota di Indonesia dalam mengeluarkan surat keterangan tidak mampu (SKTM) bisa jadi salah satu penyebab dari pengeluaran kesehatan pada rumah tangga yang tidak memiliki asuransi ini menjadi lebih rendah, karena biasanya jika mereka mengalami sakit yang harus mengeluarkan biaya yang tinggi mereka akan lebih cenderung untuk mendapatkan SKTM. Sedangkan BPPN menyatakan bahwa permasalahan yang terjadi dengan sistem asuransi kesehatan adalah ketepatan sasaran, dalam arti adanya banyak penduduk miskin dan hampir miskin yang belum tercakup dengan asuransi. Hal ini terjadi antara lain karena penggunaan database penduduk miskin yang tidak seragam. Sebagai alternatif, diterbitkan SKTM yang dapat digunakan sebagai pengganti kartu askeskin. Pada kenyataannya SKTM bisa diterbitkan tidak saja hanya untuk orang miskin tetapi juga untuk orang tidak miskin. ${ }^{(17)}$

Dalam penelitian ini yang menjadi perhatian penulis adalah antara rumah tangga yang memiliki asuransi Jamkesmas/JPKM lain dengan yang tidak memiliki asuransi kesehatan biaya OOP yang mereka keluarkan untuk kesehatan tidak memiliki selisih yang besar, bahkan dibandingkan dengan rumah tangga yang memiliki sumber asuransi yang lain rumah tangga yang tidak memiliki asuransi kesehatan justru mengeluarkan biaya yang lebih kecil.

Minh et al menyatakan bahwa ada banyak masalah perlindungan keuangan rumah tangga, terutama mereka yang termasuk kelompok yang kurang beruntung, mengalami 
pengeluaran kesehatan bencana dan/atau didorong ke dalam kemiskinan karena pembayaran biaya kesehatan. ${ }^{(18)}$

\section{Kesimpulan}

Penelitian ini membuktikan bahwa pengeluaran biaya kesehatan rumah tangga yang memiliki asuransi Jamkesmas/JPKM lain lebih kecil dibanding dengan rumah tangga yang tidak memiliki asuransi kesehatan, sementara besar pengeluaran dari rumah tangga yang memiliki asuransi Askes, Jamsostek, biaya penggantian dari perusahaan dan rumah tangga yang memiliki jaminan lebih dari satu lebih tinggi daripada keluarga yang tidak memiliki asuransi. Pengeluaran biaya kesehatan rumah tangga di Pulau Jawa lebih tinggi dari pada luar Pulau Jawa. Masih adanya pengeluaran rumah tangga untuk biaya kesehatan pada kelompok termiskin yang mana pemerintah sudah melakukan penjaminan dengan program jamkesmas, Jamkesda dan Jampersal. Masih adanya pengeluaran rumah tangga untuk biaya kesehatan yang tidak berhubungan dengan petugas atau sarana kesehatan baik pemerintah ataupun swasta.

Disarankan kepada pemerintah agar dapat mendata ulang terhadap penduduk miskin yang belum mendapat Jaminan Kesehatan terutama di daerah-daerah yang sensitive terhadap resiko terjadinya pengeluaran biaya kesehatan yang dapat menimbulkan bencana keuangan atau katastropik pada rumah tangga. Penyelenggara asuransi agar lebih meningkatkan kerja sama dengan rumah sakit swasta serta klinik kesehatan swasta dalam pelayanan terhadap peserta asuransi yang mendapatkan jaminan kesehatan. Pemerintah daerah supaya bias mencari solusi terhadap beban biaya akses bagi masyarakat miskin yang berada jauh dari pelayanan kesehatan.

\section{DaftarPustaka}

1. Thabrany H. Dasar Dasar Asuransi Kesehatan BagianA. PAMJAKI. 2005;

2. Aday LA, Begley CE, Lairson DR, Slater $\mathrm{CH}$, Richard AJ, Montoya ID. Framework for Assessing the Effectiveness, Efficiency, and Equity of Behavioral Healthcare.
1993;5:25-44.

3. Roy K, Howard DH. Equity in out-of-pocket payments for hospital care: evidence from India. Health policy (Amsterdam, Netherlands) [Internet]. 2007 Feb [cited 2012 Nov 12];80(2):297-307. Available from: http://www.ncbi.nlm.nih.gov/ pubmed/16678296

4. Fan V, Karan A, Mahal A. State Health Insurance and Out- of-Pocket Health Expenditures in Andhra Pradesh, India. 2012.

5. Erliyana E. Expanding health insurance to increase utilization does distance still mature. 2008;(December).

6. BPS. Pertumbuhan dan persebaran penduduk Indonesia, Hasil sensus penduduk tahun 2010 [Internet]. 2011. Available from: http://sp2010.bps.go.id/files/ebook/pertumbuhan dan persebaran penduduk indonesia/index.html

7. Kemenkes RI. Riset Kesehatan Dasar ( RISKESDAS ). 2010.

8. Lorenz C. Health Expenditures in Pakistan: Cross-Checking Household Expenditure Data on Health for NHA and Adjustment with National Accounts Asia Health Policy Program working paper \# 14. 2010;(650).

9. Nur Sulku DMB. Financial Burden of Health Care Expenditures: Turkey. 2012;41(3):48-64.

10. Hendrartini Y. Model Kinerja Dokter dengan Pembayaran Kapitasi dalam Program Asuransi Kesehatan. Yokyakarta: Program Doktor Ilmu Kedokteran dan Kesehatan Fakultas Kedokteran Universitas Gadjah Mada; 2010.

11. Onwujekwe O, Onoka C, Uzochukwu B, Hanson K. Constraints to universal coverage : inequities in health service use and expenditures for different health conditions and providers. International Journal for Equity in Health [Internet]. BioMed Central Ltd; 2011;10(1):50. Available from: http://www.equityhealthj.com/content/10/1/50

12. Sparrow R. Social Health Insurance for the Poor : Targeting and Impact of Indonesia 's Askeskin Program Social Health Insurance for the Poor : Targeting and Impact of 
Indonesia's Askeskin Program. 2010.

13. Parker SW, Wong R. Household income and health care expenditures in Mexico. 1997;40:237-55.

14. BPS. STATISTIK INDONESIA 2012 [Internet]. Sub Direktorat Indikator Statistik, editor. BPS; 2012. Available from: http:// www.bps.go.id/hasil_publikasi/si_2012/ index3.php?pub=Statistik Indonesia 2012

15. Xu K, Evans DB, Carrin G, Aguilar-Rivera AM, Musgrove P, Evans T. Protecting Households From Catastrophic Health Spending. Health affairs (Project Hope) [Internet]. 2007 [cited 2012 Jul 14];26(4):97283. Available from: http://www.ncbi.nlm. nih.gov/pubmed/17630440

16. Merlis M. Family OOP spending for health servis : a Continuing source of Financial insecurity. 2002;(509).

17. BPPN. Background study RPJMN 20102014 Kementerian Negara Perencanaan Pembangunan Nasional /. 2009;

18. Minh H Van, Thi N, Phuong K, Saksena P, James CD, Xu K. Social Science \& Medicine Financial burden of household out-of pocket health expenditure in Viet Nam : Findings from the National Living Standard Survey 2002e2010. 2012;2009:6-11. 